\title{
THE UNEXPLOITED POTENTIAL OF RELATIONS WITH INDONESIA, A LONG-TERM GEOSTRATEGIC PARTNERSHIP
}

\author{
Mr. Dragoș Andrei SîRBU 494
}

\begin{abstract}
Trade and investment exchanges between Romania and Indonesia are almost nonexistent. However, Indonesia, the largest economy within the Association of Southeast Asian Nations (ASEAN) and also a country on a gradually rise, consolidated and visible on the global stage, being considered the sixth emerging economy in the world, represents the premises for the exploitation of the special economic potential that can outline a geostrategic construction of the Romanian-Indonesian bilateral relations.
\end{abstract}

Keywords: EU, Indonesia, Romania, ASEAN, trade, bilateral relations, strategic partnership.

\section{INDONESIA, OVERVIEW}

\subsection{Location, population, administrative division, resources}

Indonesia lies in Southeast Asia, being located equatorially between the Indian Ocean and the Pacific Ocean, between the Australian and Asian continents. It is the largest archipelago in the world, consisting of 17,508 islands, of which about 6,000 are inhabited, with an area of $1,904,569 \mathrm{~km}^{2}$. The country is predominantly mountainous, with peaks over $4,000 \mathrm{~m}$, including over 400 volcanoes, among of which about 100 are active. The Republic of Indonesia is considered a country at high risk of natural disasters, being located on the Ring of Fire on the Pacific, a region where earthquakes occur with the intensities and the magnitudes of the highest in the world. ${ }^{495}$

It has an estimated population of $275,122,131$, ranking fourth place worldwide and consists of: Javanese (40.1\%), Sundanese (15.5\%), Malay (3.7\%), Batak (3.6\%), Madurese (3\%).

From a religious point of view, the Indonesian community is represented by Muslims (87.2\%), Protestants (7\%), Roman Catholics (2.9\%), Hindus (1.7\%).

The official language is Indonesian (Bahasa Indonesia), and other languages spoken are: English, Dutch and local dialects (about 700).

The country is divided into 7 geographical areas comprising 34 provinces, of which 5 have special status: Aceh, Jakarta, Yogyakarta, Papua, West Papua.

\footnotetext{
${ }^{494} \mathrm{Mr}$. Dragoş Andrei Sîrbu is IT Director of "Interventii Active in Atmosfera SA", a Romanian private company specialized in weather modification.

495 https://www.cia.gov/the-world-factbook/countries/indonesia/ [Site accesed last time in april 2021].
} 
The capital of Indonesia is Jakarta, with a population of 10.915 million (acc. to 2021) and other important cities are: Surabaya, Semarang, Bandung, Yogyakarta, Cirebon and Bogor (in Java), Palembang, Medan and Banda Aceh (in Sumatra), Banjarmasin and Pontianak (in Kalimantan) and Palu (in Sulawesi $)^{496}$.

Indonesia is one of the richest countries in raw materials in Southeast Asia, with significant reserves of crude oil, coal, natural gas, tin, nickel, bauxite, gold, silver, iron, copper and uranium. Among the soil resources, it is mentioned: natural rubber, palm oil, coffee, spices and tropical wood. Traditionally, production has focused on bauxite, silver and tin, but it expands to copper, nickel, gold and coal, resources meant for export.

\subsection{Short history. State structure}

Independence was proclaimed on August 17, 1945, by the creation of a republic in the islands of Java and Sumatra, by the leader of the liberation movement, Soekarno. The war of colonial liberation took place between 1945 and 1949 and the Netherlands recognized Indonesia's independence on December 27, 1949. The Republic of Indonesia was proclaimed in August 1950. ${ }^{497}$

On September 30, 1965, the Communist Party organized a coup attempt. It failed, and President Soekarno's prerogatives were severely restricted. General Soeharto led the country from March 1966 to May 1998. ${ }^{498}$ Following his resignation, Bacharuddin Yusuf Habibie, the incumbent vice-president, took over the supreme position until the holding of early elections, held on June 7, 1999. Abdurrahman Wahid (Gus Dur), leader of the National Awakening Party was President of Indonesia between 20 October 1999 and 23 July 2001. Following his resignation, the Vice President, Megawati Soekarnoputri, took over the presidency, which he held until the July 2004 presidential elections, which were won by the tandem general in reserve: Susilo Bambang Yudhoyono, President and Jusuf Kalla, vice president. Following the July 2014 elections, there were elected Joko Widodo (the former governor of the capital Jakarta), President and Jusuf Kalla, vice president. Joko Widodo won a second term in the April 2019 presidential elections, running alongside Ma'ruf Amin (deputy head of Indonesia's largest Muslim organization, Nahdlatul Ulama), against the team consisting of Prabowo Subianto (from Gerindra, the largest opposition party) and Sandiaga Uno, former deputy governor of the capital Jakarta.

Indonesia's form of government is a Republic.

The state bodies are: the People's Consultative Assembly: composed of the People's Representative Council and the Council of Regional Representatives;

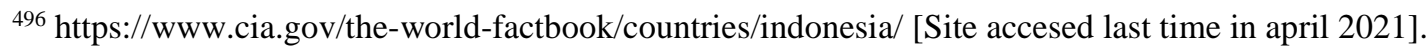

${ }^{497}$ Dumitru Tanasă, Indonezia, unitate in diversitate, 2001, p. 34.

${ }^{498}$ Dumitru Tanasă, op.cit., p. 40.
} 
The Presidency: President - Joko Widodo starting with 20 October 2014; The Supreme Court; The State Audit and The Constitutional Court.

The executive is led by the President of the state (there is no position of prime minister), who also has the quality of Supreme Commander of the Armed Forces. He is seconded by a vice-president and he appoints ministers. The president and vice president are elected for 5 years, and may have a second term.

The Legislature, respectively the Indonesian Parliament or the People's Consultative Assembly has two components: the People's Representative Council (575 members for the 2019-2024 term) and the Council of Regional Representatives (136 members for the 2019-2024 term).

Indonesia's judicial system, along with the Supreme Court, includes general, military, administrative, religious and commercial courts.

\section{ROMANIA-INDONESIA BILATERAL RELATIONS}

On February 18, 1950, the Government of Romania recognized the Republic of Indonesia as an independent state, and on July 5, 1958, the Romanian and Indonesian governments agreed to open diplomatic missions at the rank of legation.

On April 14, 1960, the level of diplomatic relations was raised to the rank of the embassy. Romania's diplomatic mission in Indonesia was opened in 1959, and in 1961, the first Indonesian ambassador to Romania presented his credentials.

On April 22, 2009, the Romanian Ambassador to the Republic of Indonesia was also appointed the Romanian Ambassador to ASEAN, an organization headquartered in Jakarta.

After 1989, both countries expressed their will to relaunch and amplify bilateral relations of cooperation in all fields, this materialized through state visits made by the presidents of the two countries in Jakarta (July 1997 and February 2004), respectively Bucharest (April 2003). The presidents of the two states also met on the sidelines of international meetings in Tokyo (November 1990), New York (September 1995) and Johannesburg (September 2002).

There is an active exchange of visits at the level of the Parliaments of the two countries, materialized through the parliamentary friendship groups, which are active in the two legislative forums.

The foreign ministers of the two countries paid visits to each other, the last being of the Romanian foreign minister in Jakarta in 2016. Political consultations on issues of regional and international interest are very important, the last round at the level of the Secretary of State MFA taking place on September 2017, in Jakarta.

There is also a good cooperation between Romania and the Republic of Indonesia, in the EU-ASEAN (Association of Southeast Asian Nations) dialogue, as well as in the ASEM (Asia-Europe Meeting). The Republic of Indonesia is, at 
the same time, an important partner for the European Union, which is keen to support our state, including through a strong partnership. In November 2009, the European Union and the Republic of Indonesia signed the Partnership and Cooperation Agreement. Negotiations for an ongoing EU-Republic of Indonesia Free Trade Agreement were launched on 18 July 2016.

\section{EU-INDONESIA RELATIONS. INDONESIA, A POTENTIAL EU STRATEGIC PARTNER}

The EU has gradually expanded its list of countries with its "strategic partners" status, so that it currently consists of: the USA, Japan, Canada, Russia, China, India, the Republic of South Africa, Brazil, Mexico and South Korea ${ }^{499}$.

Including Indonesia on the list of strategic partners would be equivalent to recognizing the EU's role on the global stage and, at the same time, raising the cooperation relationship to a higher level ${ }^{500}$.

In Asia, the EU also concluded negotiations for a Free Trade Agreement with Singapore in December 2012 (to be ratified after filling in the technical procedures) and is effectively engaged in trade negotiations with India (since June 2007), Malaysia (since October 2010), Vietnam (since June 2012), Thailand and Japan (since March 2013) ${ }^{501}$.

Although the EU does not yet engage in trade negotiations with Indonesia, it is considered that this country corresponds to the "profile" of a priority partner, taking into account: its size (as GDP, population, area), the richness and variety of natural resources, its geopolitical importance, position its geographical relationship between China and India, its membership of the G-20, its active participation in the Asia-Pacific Economic Cooperation (APEC) Forum and its key role in ASEAN. Its intense involvement on the international stage is also highlighted by its membership in: the Cairns Group (of countries with competitive agriculture), the World Trade Organization, the Organization for Islamic Cooperation (being, by the way, the country with the largest Muslim population in the world $)^{502}$.

Indonesia accounts for about $40 \%$ of ASEAN's population and GDP, but it is only the fourth largest EU trading partner in the group, after Singapore, Malaysia and Thailand. ASEAN, as a whole, is the fifth non-EU partner, behind the USA, China, Russia and Switzerland ${ }^{503}$. Trade in goods between the EU and ASEAN's largest economy totaled $€ 25$ billion in 2012 - only half of the EU's trade in goods with Singapore ${ }^{504}$. Therefore, there is a significant gap between the

\footnotetext{
${ }^{499}$ Oehler-Şincai, 2013.

${ }^{500}$ Loewen, Spandler, 2013, p. 52.

${ }^{501}$ European Commission, 2014.

502 Newby, 2004, p. 101, Weissmann, p. 11.

${ }^{503}$ DG Trade, 2013.

${ }^{504}$ DG Trade, 2014.
} 
potential and expectations of the EU-Indonesia relationship, which can be capitalized on in the next period.

It is worth mentioning the intensification of Indonesia's relations with Australia, India, Japan, Kazakhstan, Myanmar, Papua New Guinea, Solomon Islands, East Timor in Asia, with Saudi Arabia in the Middle East, Liberia and Nigeria in Africa, Poland, Sweden, the Russian Federation and Belarus, Germany, the Netherlands, France in Europe, Argentina, Mexico and Peru in Latin America, especially during 2013. At the regional level, Indonesia has been actively involved in launching consultations between ASEAN and China on the Code of Conduct in the South China Sea. Under the chairmanship of the APEC Forum, Indonesia has introduced two new priorities on the APEC agenda: sustainable and equitable economic growth and promoting connectivity between APEC countries, not only through regional economic integration but also through intercultural connections $^{505}$.

According to a recent study, Indonesia's poorly developed infrastructure is the main factor preventing the achievement of a potential rate of economic growth of $8 \%$ nationally and this also reflects on inflation ${ }^{506}$. Despite legislative progress, international experts appreciate that the discrepancy between legislation and customs is appreciable and that cohesion of regulations between different regions of the country and the removal of obstacles to inter-regional projects are needed $^{507}$.

In this context, it should be emphasized that Indonesia cannot achieve the ambitious goals mentioned above in the absence of substantial financial resources (from exports, FDI), public-private partnerships and access to new technologies. Thus, it becomes obvious the role that the EU and its member states can play in the process of modernization and innovation of Indonesia, as in the case of other emerging economies ${ }^{508}$.

Certainly, Indonesia alone cannot achieve its ambitious goal of becoming one of the world's top ten economies by 2025 . Its bold economic, social, and environmental goals cannot be achieved without significant financial resources and access to new technologies. The fact that the EU is ready to intensify bilateral relations is demonstrated by political statements since $2011^{509}$. Its motivation to strengthen bilateral relations is found in the very development potential of this young democratic state, which is booming on the path of sustainable growth.

\footnotetext{
505 The Jakarta Post, 2014, RSIS, 2013.

${ }^{506}$ Standard Chartered, 2011, p. 2.

${ }^{507}$ Indonesia Investment, 2013.

${ }^{508}$ Oehler-Şincai, 2012.

${ }^{509}$ European Commission, 2011.
} 


\section{ROMANIAN-INDONESIAN RELATIONS, PARTNERSHIP FOR THE FUTURE}

In recent years, bilateral meetings at embassy level have intensified, on which occasions officials have reaffirmed their desire to contribute to the development of relations between the two states, especially the intensification of cooperation relations in areas of common interest, such as health, education, energy, digital governance, climate change and sustainable development.

The foreign ministers appreciated the positive evolutions registered in the Romanian-Indonesian relations, marked in the last years by frequent contacts at parliamentary and governmental level. They highlighted the prospects of maintaining this dynamic in the next period, including through high-level visits, in the context of the constant efforts of both states to promote their bilateral relations, with emphasis on intensifying the economic and trade component of their relations.

The chambers of commerce and industry of the two states have an important role in the significant potential for consolidating and diversifying the RomanianIndonesian economic relations, in sectors such as agriculture, renewable energy, railways and IT, as well as for the interest shown by the business community in both states, in capitalizing on existing opportunities.

In the last years Romania was one of the top partners of trade from the Eastern Europe. In 2020 the total trade was in the sum of 153 milion \$ with an increase of $0.79 \%$ compared to last year (Tabel 1 ).

Tabel 1 - Balance of Trade between Indonesia and Romania (In thousands US\$)

\begin{tabular}{|l|c|c|c|c|c|c|c|c|c|}
\hline $\begin{array}{l}\text { Descrip- } \\
\text { tion }\end{array}$ & $\mathbf{2 0 1 6}$ & $\mathbf{2 0 1 7}$ & $\mathbf{2 0 1 8}$ & $\mathbf{2 0 1 9}$ & $\mathbf{2 0 2 0}$ & $\begin{array}{c}\text { Trend } \\
(\%) \\
\mathbf{1 6 - 2 0}\end{array}$ & \multicolumn{2}{|c|}{$\begin{array}{c}\text { Jan-Mar } \\
\mathbf{2 0 2 0 - 2 0 2 1}\end{array}$} & $\begin{array}{c}\text { Mod. } \\
(\%) \\
\mathbf{2 1} / \mathbf{2 0}\end{array}$ \\
\hline $\begin{array}{l}\text { TOTAL } \\
\text { Trade }\end{array}$ & $134,555.3$ & $172,067.8$ & $144,778.1$ & $152,214.4$ & $153,428.4$ & 1,41 & 58,6 & $44,035.5$ & $-24,89$ \\
\hline $\begin{array}{l}\text { Export - } \\
\text { Indonezia } \\
\text {-Romania }\end{array}$ & $92,479.5$ & $125,041.5$ & $107,369.5$ & $128,006.2$ & $108,985.5$ & 3,58 & 36,1 & $34,959.2$ & $-3,31$ \\
\hline $\begin{array}{l}\text { Import } \\
\text { Indonezia } \\
\text {-Romania }\end{array}$ & $42,075.9$ & $47,026.3$ & $37,408.6$ & $24,208.2$ & $44,442.9$ & $-5,39$ & 22,4 & $9,076.3$ & $-59,61$ \\
\hline $\begin{array}{l}\text { Balance of } \\
\text { Trade }\end{array}$ & $50,403.6$ & $78,015.1$ & $69,960.9$ & $103,798.0$ & $64,542.6$ & 8,11 & 84.4 & $25,882.9$ & 89,14 \\
\hline
\end{tabular}

https://statistik.kemendag.go.id/balance-of-trade-with-trade-partner-country ${ }^{510}$

\footnotetext{
510 https://statistik.kemendag.go.id/balance-of-trade-with-trade-partner-country [Site accesed last time in april
} 2021]. 
The signing ceremony of the inter-harbor collaboration between PT Pelindo II and CN APM SA Constanța took place on February 18, 2020 in Constanța. The bilateral agreement becomes the first of its kind in Eastern Europe and marks 70 years of bilateral relations between Indonesia and Romania. Both signatory parties are the most important harbor operators in Indonesia and Romania. The parties also agreed that the harbor of Constanța would become a 'hub' through which goods from Indonesia could reach more easily the markets in Central and Eastern Europe, as well as Central Asia. On the other hand, Tanjung Priuk, the largest harbor in Indonesia, should be a 'hub' for Romanian goods to reach Southeast Asian markets.

The Memorandum of Agreement includes 6 areas: environment, investments, information exchange, modernization and improvement of multimodal transport, market research, training and staff exchanges.

The harbor of Constanța is open for outbound investments in Indonesia. The Romanian side emphasized the importance of the Danube River and the harbor of Constanța as a more efficient and economical way to transport goods, compared to land transport. They also proposed to the Indonesian side to participate in the opening of a specialized terminal for fertilizers and vegetable oils. It was also discussed the possibility for Romanian businessmen to import coal with a low sulfur composition for thermal power plants in Romania.

Given the existing opportunities, the Indonesian Embassy in Bucharest will work with other stakeholders to identify other goods that can be exported to Russia, Eastern and Central Europe, as well as to Central Asian markets.

The list of products exported to Indonesia included: gas and oil pipelines, cast iron, iron or steel products, replacement parts for railways, machine tools and replacement parts, $6 \times 6$ truck components, cauldrons and boilers, parts and equipment for the petroleum industry, marble and granite products, wood or articles thereof, chemicals, base metals, textiles.

Romania imported from Indonesia: plastics, natural rubber, coffee, electrical and electronic equipment, toys, rattan furniture, palm oil, sweets and various fabrics.

\section{CONCLUSIONS}

Indonesia is one of the countries in the world with the most robust economic growth in recent times, which has managed to counteract most of the effects of the global financial and economic crisis. Indonesia ranks 4th in the world in terms of population and 15th and 16th in terms of area and nominal GDP, respectively. Its active population is projected at $60 \%$ of the total population by 2030 , and its middle class may double by 2020 .

Although the EU is not yet engaged in trade negotiations with Indonesia, it is believed that this country corresponds to the "profile" of the Union's priority partner, taking into account not only its size (as GDP, population, area), but also 
the richness and variety of natural resources, its geopolitical importance, its geographical position between China and India, its membership of the G-20, its active participation in the Asia-Pacific Economic Cooperation (APEC) Forum and its key role in ASEAN. Moreover, the historical ties between Indonesia and the Netherlands are an asset for the latter in EU-Indonesia relations ${ }^{511}$.

Indonesia accounts for about $40 \%$ of ASEAN's population and GDP, but it is only the fourth-largest EU trading partner in the group, after Singapore, Malaysia and Thailand. This fact shows a significant gap between the potential and expectations of the EU - Indonesia relationship, which can be capitalized in the next period.

As recent studies show ${ }^{512}$, a possible Free Trade Agreement with the EU should take into account all the weaknesses of the Indonesian economy and help reduce them. Only in this way can Indonesia achieve its economic, social and environmental goals.

As infrastructure develops and businesses costs in / with Indonesia decrease, trade, investment, technology flow between Indonesia and EU member states (Romania), as well as other economies, both developed and emerging, which will intensify ${ }^{513}$.

Indonesia's willingness to enter the list of the world's top ten economies by 2025 should not be seen as a threat, but as a factor of stability and development in Asia and, implicitly, globally.

\section{BIBLIOGRAPHY}

- Antara News (2014), Indonesia, Netherlands reach comprehensive partnership, March 16.

- Antara News (2012), RI, Germany agreed to become strategic partners, 10.07.2012.

- Chandra, A. C., Manurung, A. A., Pambudi, D., Pakpahan, B. (2010), Hopes and Fears: Indonesia's Prospects in an ASEAN-EU Free Trade Agreement, International Institute for Sustainable Development, Canada.

- Indonesia Investment (2013), Public-Private Partnership Projects in Indonesia Remain Troublesome, September 28.

- Loewen, H., Spandler, K. (2013), Indonesien und die EU: Mehr Handel als Handeln, in: Lang, K.-O., Wacker, G. (Hg.), Die EU im Beziehungsgefüge grosser Staaten, SWP Studie, S 25, Berlin.

- KPMG (2013), Investing in Indonesia.

- DG Trade (2013), Countries and Regions - Indonesia, September.

\footnotetext{
511 Ohler-Şincai, 2014.

${ }^{512}$ Chandra et al., 2010.

${ }^{513}$ Ohler -Şincai, 2014.
} 
- DG Trade (2014), Bază de date a CE privind statistica de comert exterior, http://ec.Europa.eu/trade/creating-opportunities/bilateral-relations/statistics/.

- European Commission (2006), Indonesia Country Strategy Paper 2007-2013, Brussels.

- European Commission (2001), Indonesia Country Strategy Paper 2002-2006, Brussels.

- European Commission (2011), Invigorating the Indonesia-EU Partnership, Towards a Comprehensive Economic Partnership Agreement, http://eeas. europa.eu/delegations/indonesia/documents/press_corner/20110615_01_en.pdf.

- European Parliamentary Research Service (2014), EU-Indonesia agreement on trade in illegal timber, Briefing 20/02/2014.

- Matei H. C., Neguţ, S., Nicolae, I. (2005), Enciclopedia statelor lumii, Meronia Publishing House, Bucharest.

- Newby G. D. (2004), A Concise Encyclopedia of Islam, Oneworld, Oxford, England.

- Oehler-Şincai, I. M. (2012), Comerţul cu partenerii strategici ai UE experienţa comunitară şi românească, Economic Tribune, 200 pages, Bucharest.

- Oehler-Şincai, I. M. (coordonator) (2013), Reconfigurarea politicii externe comunitare, in contextul mutaţiilor din plan global, programul „Mutaţii structurale în economia mondială”, INCE/IEM, Academia Română, București.

- Oehler-Șincai, Challenges of doing in the Global Economy, 16-17 May 2014.

- Rajaratnam School of International Studies (RSIS) (2013), Indonesia's APEC Chairmanship of 2013: Key Priorities and Future Agenda, RSIS Policy Report.

- Standard Chartered (2011). Indonesia - Infrastructure Bottlenecks, Special Report.

- Tanasă D., Indonezia, unitate in diversitate, 2001.

- The Jakarta Post (2014), Assessing President Yudhoyono's Foreign Policy in 2013, Yayan GH Mulyana, Jakarta, March 3.

- Weissmann, M. (2013), A European Strategy Towards East Asia - Moving from Good Intentions to Action, Swedish Institute of International Affairs, Occasional Paper No. 19.

- www.mae.ro.

- https://jakarta.mae.ro/node/484.

- https://jakarta.mae.ro/node/221.

- https://www.cia.gov.

- https://www.cia.gov/the-world-factbook/countries/indonesia/.

- https://kemlu.go.id.

- https://statistik.kemendag.go.id/balance-of-trade-with-trade-partner-country. 